Brazilian Journal of Political Economy, vol. 30, $n^{\circ} 3$ (119), pp. 420-437 July-September/2010

\title{
Karl Polanyi, Athens and us: The contemporary significance of Polanyi's thought
}

\author{
BERNARDO STUHLBERGER WJUNISKI \\ RAMÓN G. FERNANDEZ*
}

Karl Polanyi is considered one of the most prominent social scientists of the 20th century. In his writings, an important concern was the relationship between the markets and the society (therefore, the state) as a whole; to discuss it, he introduced the concept of "embeddedness", fundamental for his study of the origins and consequences of the Industrial Revolution. An important part of his heritage is the study of the economic history of what he called "ancient societies," especially of Classical Greece. Polanyi used these studies to compare the ancient societies with his own times, in an effort to understand them all. This paper aims to relate Polanyi's work on the Athenian society with his studies about the modern times, showing that it is possible to draw lessons from Polanyi's thought on the relationship between the society, the state and the market that can help to design a political agenda for our days. In the first part, we present the most important aspects o the life and work of Polanyi, and in the second we discuss the most important aspects of his worldview. Then, in the third part, we study his view of the early Athenian economy; mainly, we focus on the coexistence of a kind of state planning and a market, showing how this understanding is crucial for the whole Polanyian legacy, with its emphasis in the comparison of different societies and times. We conclude by underlining the relevance of this interpretation advanced by Polanyi to understand the societies of our days, focusing on some proposals to extend his approach to deal with our contemporary problems.

Keywords: Karl Polanyi; embeddedness; classical Greek economy.

JEL Classification: B25; N30; Z13.

\footnotetext{
* Msc in Economic History candidate at the London School of Economics (LSE). B.A. in Economics, Escola de Economia de São Paulo (FGV/EESP). E-mail: bew@terra.com.br; Associate Professor, Escola de Economia de São Paulo (FGV/EESP). E-mail: ramon.fernandez@fgv.br. We gratefully thank the comments made by an anonymous referee of this journal. Submitted: May 2008; Approved: February 2009.
} 
"...the Greeks of antiquity, whose genius was already credited with giving birth to our politics, philosophy, science, and art, were also the initiators of all advanced buman economy." (Polanyi, 1977, p. 146)

Karl Polanyi is considered one of the leading social scientist of the twentieth century. He was a very engaged person, and one of his efforts was to try to understand the changes of the society of his time. To do so, while writing his famous book "The Great Transformation" he understood that to comprehend his own time was necessary to compare it with different ones. In this sense, he came to study what he called the "ancient societies", in an effort to understand the way people dealt through history with the material aspects of live, what he called "the problem of human livelihood" (Polanyi, 1977, p. xxxix). As a result, an important part of his legacy is the study of the economic history of those ancient societies, especially of Classical Greece, making some major contributions to the way we understand those economies nowadays. One of the most interesting results of his analysis was the discussion of the organization of those economies, showing the similarities between their societies and ours.

This paper aims to study Polanyi's interpretation of those societies, especially the ancient Greek economy, looking for what can be learned for our present situation from his analyses of those times. We discuss, therefore, the contemporary significance of Polanyi's ideas and how they can be applied in our globalized world.

Our main motivation is the belief that economic history and the study of past societies are very important tools to understand our own economy and times. Many lessons and policy prescriptions can be learned from their successes and mistakes. Besides, those comparisons allow us to better understand which features of our society can be considered common to all civilized societies, and which ones constitute specific aspects of the societies of our own times. Specifically, we understand that the tensions between market and state are a common feature present in our economies and the earlier ones.

This paper is organized in four sections, besides this one which introduces the article. The following discusses the life and work of Karl Polanyi. On the second section we discuss his worldview, presenting his main ideas and concepts. In the third section we present the Polanyian analysis of the ancient Athenian economy. The fourth section closes the paper, discussing some lessons drawn from his work which can help us in the understanding of our contemporary issues.

\section{KARL POLANYI: HIS LIFE AND WORK}

Karl Polanyi is considered one of the leading figures of the twentieth century in the fields of Economics, History, Anthropology and Sociology. His main concern was to try to understand how human beings organize themselves as to deal with 
the material aspects of their lives. To do that, he studied such subjects as the markets, trade and other economic institutions, trying to understand how they affect the lives of the human beings. He always worked within a perspective strongly critical in relation both to the orthodox economic paradigm and to economic liberalism (Baum, 1996). Polanyi never believed that people have an insatiable thirst for material wealth, being a harsh critic of the idea that the economic problem is a result of a clash between people's allegedly unlimited desires and the scarce resources of their societies.

Polanyi wrote some very important books about a wide variety of subjects in economic history. In all of them is clear his concern to show, through contrasts and comparisons, the specificity of the capitalist economies, emphasizing its differences with all previous societies. One of his books, The Great Transformation, is considered not only his main work, but also one of the most important books in the social sciences in the past century. ${ }^{1}$ Polanyi analyzes in it the social consequences of the economic organization of the societies of the $19^{\text {th }}$ century.

The writings of Polanyi constitute an important source for the knowledge of the economic history of the ancient civilizations, but at the same time these works shed light on our contemporary situation. As a result of the originality of his perspective, Polanyi and his followers came to be considered as founders of a distinct school of economic (and social) thought, known as substantivism (Johnson \& Earle, 2000).

Karl Polanyi was born in Vienna on October 21, 1886, but he lived all his childhood in Budapest. These two places were the most important cities of the Austro-Hungarian Empire. His father had been born in nowadays Slovakia, while his mother came from present Lithuania; both his parents were Jewish. Although later they "magyarized" culturally, even changing the family name (originally Pollacsek), Karl and his three siblings (including the famous chemist and philosopher Michael) were raised amidst the intellectual Jewish elite of the Hungarian capital. $^{2}$

Polanyi graduated in Law in Hungary. During those years, he became the first president of the Galilei Circle, a student organization founded in 1908, some of whose members later participated both of the democratic government after the end of the First War, and of the Communist Revolution led by Bela Kun in 1919. Polanyi moved to Vienna in 1919, and there he worked as associated editor of Der Oesterreichische Volkswirt, a very important periodical, from 1924 to 1933.

As the strength of the Nazis began to increase in Austria, Polanyi moved to England, where he arrived in 1933. There he taught courses on European History organized by the extramural department of Oxford University and later also at the University of London. By the end of that decade, he began to give lectures in the

\footnotetext{
${ }^{1}$ Rather surprisingly, it was included in the list "One hundred most influential books since World War II" on the Oct 6, 1995, issue of The Times Literary Supplement.

${ }^{2}$ The biographical information is essentially based on Stanfield, 1986, ch.1.
} 
USA, where he was at the start of the Second World War. He stayed there from 1940 to 1943, working at Bennington College, where he wrote most of The Great Transformation (though the beginning and the end of the book were written in England). In 1947 he was appointed Visiting Professor of Economics at the University of Columbia, where he mainly taught economic history; there he wrote the essays collected in The Livelihood of Man, posthumously published in 1977.

Polanyi retired in 1953, but he maintained his relationship with Columbia working in a project, directed by Conrad Arensberg and himself, on the institutional aspects of economic growth. This would have an enormous impact on the development of the whole field of economic anthropology, and resulted in the book Trade and Markets in the Early Empires (organized by Polanyi, Arensberg and Harry Pearson). Polanyi died on April 23, 1964. His book Dahomey and the Slave Trade was published in 1966, and some of his essays were edited by George Dalton and published in 1968 as Primitive, Archaic and Modern Economies.

It would be difficult to exaggerate the impact of the work of Polanyi in the social sciences of the USA in the twentieth century. As an example, A. Latham (1998, p. 4) wrote that:

Trade and Markets together with the Columbia seminars had an enormous impact on United States economic history and economic anthropology. Names associated with the project were David Landes, Margaret Mead, Marshall Sahlins, Moses Finley, Walter Neale, Harry Pearson and many others, together with outright disciples like Paul Bohannan and George Dalton. One might say that beneath the surface of an American social scientist of that generation, you will find a Polanyist, just as beneath the surface of a British social scientist of that period you will find a Marxist.

It will be helpful to make some short comments on the main works of Polanyi mentioned above. The most important one, The Great Transformation, studies the constitution of capitalism in Europe, especially in England, in the $19^{\text {th }}$ century, and its social consequences. Block (2001, p. xviii) affirms that it provides “...the most powerful critique yet produced of market liberalism - the belief that both national societies and the global economy should be organized through self regulating markets". In this book, he develops the concept of the Double Movement. According to Polanyi (2001, p. 79) "the extension of the market organization in respect to genuine commodities was accompanied by its restriction in respect to the fictitious ones [i.e., labor, land and money]", a movement which can be understood as a reaction by the people living in the market economies to the increasing commoditization of some aspects of life (namely, people and their environment) that were being seriously impaired by this process.

Some central insights of this book represent the first formulations of the basic agreements of the substantivist school, which maintains that the study of the economic aspects of any society should stress the role of its culture, its institutions and 
its history; or, to put it in Polanyi's terms, should recognize that the economy is embedded in the society. It is important to stress that for Polanyi and his followers, the object of economics is the study of how people satisfy their material needs, "...shifting the emphasis from a type of rational action to the configuration of goods' and persons' movements which actually make up the economy" (Polanyi, Aresnberg \& Pearson, 1957, p. 242).

As a consequence, Polanyi and his followers turned their attention to the study of the alternative ways in which people dealt with the material (economic) aspects of life in different places and times, the study of the "Primitive and Archaic societies". One of their main concerns was to show that the self-regulating markets had not been the only way mankind found to organize the production and distribution of goods, and in some cases it had not been the best one. According to Polanyi (2001, p. 48), “...man's economy, as rule, is submerged in his social relations” but in the capitalist societies, "...the control of the economic system by the market is of overwhelming consequence to the whole organization of society: it means no less than the running of society as an adjunct to the market. Instead of the economy being embedded in the social relations, social relations are embedded in the economic system" (2001, p. 60). Gregory Baum characterizes this approach as showing that throughout history the economy "...in short, was accessory to society" (1996, p. 12).

To criticize the modern economy, these authors took the examples of the ancient ones. As a result, different studies of former societies were published, many of them included in Trade and Markets in the Early Empires, the volume edited by Polanyi, Arensberg and Pearson (1957); in the same vein Polanyi wrote his essays collected in The livelihood of man (in which there is a special concern with the classical Greek societies) and in Primitive, Archaic and Modern Economies. According to Stanfield, "He studied early economic systems to provide perspective and depth for his analysis of market capitalism and his dissent from its characteristic economic thought" (1994, p. 166).

It must be noticed that for Polanyi and the substantivists, the concept of Ancient Economies is not confined to Antiquity. They apply this term to different societies, including the primitive contemporary ones which are not governed by the market mechanism. Polanyi stressed that historical and anthropological studies were the basis of his perspective. As an illustration, in chapter IV of The Great Transformation, examples taken from ancient and primitive economies are interchangeably used to contrast them with the modern market society.

The impact of the work of Polanyi went well beyond his lifetime. His main insights are lively discussed nowadays. One of the main institutions promoting works along these lines is the Karl Polanyi Institute of Political Economy, founded in 1987 and based in Concordia University, in Montreal, Canada, and created “...in response to the growing recognition of the relevance of Karl Polanyi's work to contemporary 
society". ${ }^{3}$ This institute publishes works written from a substantivist perspective both on Ancient Economies (e.g., Tandy, 2001), as well as on the contemporary ones (e.g., Adaman \& Devine, 2002). The Institute holds some international conferences; the tenth was held in Istanbul in 2005; the next one will be held in Montreal at the end of 2008 .

\section{POLANYI'S WORLDVIEW}

The objective of this section is to present and discuss Polanyi's worldview. To understand the contemporary significance of Polanyi's ideas, we initially need to introduce some fundamental concepts he developed, still discussed and employed in our days, which obtained great impact inside and outside the academy.

The Great Transformation can be considered the most important work of Polanyi. In this book he discusses the economic and social implications of the industrial revolution. Its main thesis is that the evolution of capitalism and the industrial revolution occurred together with a combination of two important forces: the development of the self regulating market and the consolidation of the liberal creed that was to be the cornerstone of the policies of the modern state. According to him, the consequences of the evolution of these two forces have disruptive social implications.

The first force, the self regulating market, corresponds to the development of a complete liberal market organization in the economy. According to Polanyi, markets and the economy should be an accessory to social relations, a means to help the exchange of goods and services, but they should never replace the social relations, as it occurred during the industrial revolution and afterwards. The completely free (liberal) market has a disruptive side, because it transforms all the features of social life into marketable goods, as reflected, for example, in the constitution of a labor market. The social consequence of this complete freedom for the market is the removal of the human side from the economic aspects of life; we can take as an example what happened in England during the $19^{\text {th }}$ century, when children and women were forced to work up to 20 hours a day. So, the first force that developed together with capitalism was the evolution of this market pattern (Polanyi, 2001).

But, as these markets began to dominate the society, this process created social discontent. To protect these markets emerged the liberal creed, safeguarded by the national states. This ideology can be considered the way found by those who benefit from the existence of the free markets to protect them, to convince the society that it is the best imaginable economic system, and that therefore it should be preserved. Besides, the defense of this creed by the governments was an important way

\footnotetext{
${ }^{3}$ http://artsandscience.concordia.ca/polanyi/. Access on April 15, 2007.
} 
to maintain the situation under control. This is the second force mentioned above (Polanyi, 2001).

These changes occurred during the $19^{\text {th }}$ century implied the destruction of the basic social order that had existed throughout all the previous and very different societies in the history of mankind. Polanyi's empirical case relied largely on the analysis of the Speenhamland laws, which he saw not only as the last attempt to preserve the traditional system of production and social order, but also as a self-defensive measure on the part of the society to mitigate the disruption of this violent period of economic change (Polanyi, 2001). ${ }^{4}$

In this sense, Polanyi argues that the development of the modern state went side by side with the development of the self regulating markets, and that these two changes were inevitably related in history. His argument for this was that the modern state, although typically considered a shrinking one, was actually very strong as to force the changes in the social structure that made possible the birth of a competitive capitalist economy, and at the same time this economy required a strong reaction of the society to mitigate its disruptive effects. This process was called by him double movement, because one force is a reaction to the other one: the evolution of the markets and the development of the liberal creed forced the society to protect itself. In Polanyi's words:

For a century the dynamics of modern society was governed by a double movement: the market expanded continuously but this movement was met by a countermovement checking the expansion in definite directions. Vital though such a countermovement was for the protection of society, in the last analysis it was incompatible with the self-regulation of the market, and thus with the market system itself." (Polanyi, 2001, p. 136)

Besides the double movement, a second important idea developed by Polanyi is the concept of embeddedness, briefly discussed in the first section. This concept is central for his theoretical framework, because it allows him to show why the organization of the economy with completely free markets is not a basic need of mankind. Block (2001, p. xxiv) explains that embeddedness “...expresses the idea that the economy is not autonomous, as it must be in economic theory, but subordinated to politics, religion, and social relations".

So, the economy is not separated from other social activities and relations, but it is part of the life of each human being. Polanyi argues that the organization of the society around self regulating markets and the emergence of their disruptive side was only possible when the economy became disembedded, something that

\footnotetext{
${ }^{4}$ These measures are typically considered as failures because they could not prevent the advancement of the markets, capitalism, etc. Interestingly, Polanyi $(2001$, p. 39) says that these attempts actually succeeded, because they managed to slow down the pace of the changes, which were in a certain sense unavoidable, so it was the best result they could achieve.
} 
happened during the industrial revolution and its aftermath, clashing with the normal way in which men dealt with the economics aspects of life.

According to Polanyi, the embeddedness was something natural for the ancient societies (an idea we explore below), and that way of organizing life still has many things to teach to us, as the process of disembedding the economy had dire social consequences.

A central part of Polanyi's analysis is the development of the concept of "fictitious commodities". In his view, when the markets expand so much that everything in human life becomes tradable, some important aspects of life are transformed into commodities, but this process is by nature fictitious, because they do not have the qualities needed to be transacted in the market, as they are not produced to be sold. For Polanyi, the fictitious commodities are land, labor and money, things that in an embedded economy would never be allocated through the market (Polanyi, 2001). The existence of these fictitious commodities is a direct result of the (unchecked) development of the self regulating market, and its consequences are the transformation of nature and people into commodities.

Finally, and as a consequence of his analysis of the social transformations caused by the industrial revolution, Polanyi developed a strong criticism of the liberal ideology. He understood that the rise of capitalism was based on an imposed creed and on an imposed market society, both not natural in human development; he argued that laissez-faire was planned, and that the double movement was a process always refueled by society and by the national states. The problems raised by neo-liberalism today show that this criticism is still valid.

The next section presents Polanyi's analysis of the Athenian Economy, showing the importance of the ancient societies for his worldview; fundamentally, he considered that they were different from ours because their economies were always embedded in their social relations.

\section{THE POLANYIAN ANALYSIS OF THE ATHENIAN ECONOMY}

For Polanyi, the Athenian society was one of the major examples of a place where the concept of embeddedness applied. From his perspective, in Athens and mostly everywhere in ancient Greece the economy was not separated from the rest of the political and social activities of each citizen. The Greeks did not try to achieve economic goals when taking all their decisions. They chose according to other criteria, like politics, welfare, family or any other that was important for their life. Economic rationality (in the sense of maximizing and self-regarding objectives) was not the criterion for economic decisions (Polanyi, 1968).

This concept is emphasized by Polanyi during his analysis of the Athenian economy, and it is one of the major contributions of his works on ancient societies, as it corresponds to a different way of observing the place of the economy in society. The whole Polanyian analysis is based on it, as he was always trying to see 
which social factors caused the economic decisions in that society and not assuming apriori the rationality of those decisions.

Other idea that plays an important role in his interpretation of the Athenian economy is his understanding of the coexistence of the market and the state. Athens had two economic spheres at the same time: an internal market, the agora, which coexisted with state planning over of the economy. In Polanyi's words (1977, p.145):

The outstanding facts are, on the one hand, that trade and money, mainly through the use of small coin, were linked with market elements in the Athenian agora; on the other, that not much later in Egypt, and again under Greek leadership, the methods of storage and redistribution inherited from ancient Pharaohs were raised to the level of sophisticated economic planning.

This duality is discussed by him during all his analyses. The main question that Polanyi tries to answer is why Athens chose a system combining both market and state planning, instead of choosing only one of these options.

This section tries to answer this question, showing the reasons Polanyi gives on why Athens chose this specific and impressive economic system. It also has the purpose of giving an overview of his interpretation of the Athenian economy, reminding that the concept of embeddedness applies to it. In other words, this section tries to presents the main points of Polanyi's work on the Athenian society.

\section{The Classical Athenian Economy: The Three Spheres}

Ancient Greek history is divided into three main periods: the Archaic, the Classical and the Hellenistic. ${ }^{5}$ The Archaic period is the beginning of the Greek history, a time were the polis did not exist and the society was based on independent producers, who lived isolated from each other; social institutions were weak, and so it was a period of constant disputes among the farmers. At his time, people were neither organized in villages nor in cities proper. Besides, it is also a period on which we do not have many sources, and thus our knowledge about it is rather small (Polanyi, 1977, ch. 11).

Classical Greece is the most important period, and the most studied one, of Greek history. It corresponds to the fifth and fourth centuries B.C. It was a time of richness and glory, of the polis and the democracy. It is also the time of a singular economic organization (the dual system) and the major focus of Polanyi's research in his last decades of life.

The Hellenistic period is the time of the dominance of Greece by the

\footnotetext{
${ }^{5}$ To see more about the Greek economic history and its three main periods see Finley (1991) and Austin \& Vidal-Naquet (1977).
} 
Macedonians, and the Empire of Alexander. This is the time were the polis no longer existed and when the classic system studied by Polanyi disappeared.

This paper discusses the Classical period and Polanyi's view of it, more specifically based on the example of Athens. At the end of the section, some considerations are made also about the Hellenistic period and the fall of the Greek society.

Polanyi used Athens as his major focus of study and as a permanent reference during his analysis because of its importance. First, it was by far the most important city of that time, in economic and political terms. Second, it was also the city which developed the highest standards of economic organization, besides its spectacular cultural achievements. And third, it is the best example of the use of the dual system that Polanyi observed in that time. Thus, as it was for Polanyi, Athens will be our focus and example in this paper.

Polanyi divided the Athenian economy into three main spheres: the patriarchal economy, the market, and the state planning, being the last two the most important. The first one, the patriarchal economy, essentially existed in the big, rich and traditional families. The foodstuff were produced, stored and distributed for all the family. This sphere had its origin in the old tribes and still existed in the polis. The family was responsible for all of its members (including its slaves), needing to provide at least the minimum necessary to live. This sphere is important because of its distributive facet, the principle of taking care of the family as a whole, something that would appear again in different ways in the other economic forms in Greece (Polanyi, 1977, ch. 12).

The second sphere was the market, the agora, whose objective was to allocate efficiently the resources, improving the daily supply of the foodstuff in the economy. It was essentially used by small families or by free workers, who had the necessity of selling its products quickly and who had not conditions to store resources like the big families did. It had also a redistributive function, which will be explained below.

The third sphere was the state planning, main articulator of the economy; it had the function of watching over the supply of foodstuff and also to protect the economy from external shocks. The state could make any kind of intervention in the market with the purpose of guaranteeing the supply and controlling prices. The state had to control the amount of imports of foreign products, mainly grains, and also had to store food for the periods of bad crops. The basic idea was that the state could and should do all the available policies to care for the needs of its citizens. Sometimes this could be done without taking efficiency into account, although this criterion was normally relevant, but to consider the necessities of its citizens was the main objective of the state which, when necessary, interfered in the economy without looking for efficiency (Polanyi, 1977, ch. 12).

The state intervened in the market any time it found it necessary, controlling supplies, fixing prices, taking indeed any policies required to assure the supply of foodstuff for the city. From this perspective Polanyi said that the market played a redistributive role: it was controlled by the state to reach its objectives. It was better for the city to allow the market to allocate many goods efficiently by its own 
means in normal periods, but in moments of crisis the city intervened to make the market work for the city's interests (Polanyi, 1977, ch. 12).

This is one of the most important ideas in Polanyi's analysis of the Athenian economy. The market had limits, and these limits were decided by the state. While the market worked well and foodstuff was granted for the city at normal prices, the market could function freely, and the city understood that this was an efficient way of allocating goods. But in moments of crisis, when there was lack of foodstuff or when prices were too high for what was considered reasonable, the city intervened in the economy with any policy necessary to stabilize it again.

This was the basic principle of the economy of Athens in the classical period: to provide foodstuff for the citizens so that everyone would get the minimum requirements to live, taking efficiency as much as possible into account. So, the market was used by the state as a mechanism to carry on such policy, but the state intervened when the authorities thought that the market was not achieving that purpose. The economy was embedded in the objectives of the Athenian society, and the market was bound by the limits of the city.

\section{Market versus State: The duality}

The most important characteristic of the Athenian economy within this perspective was this duality between State and Market. The domestic market had the objective to place efficiently the resources and also served as a redistributive mechanism for the state; its participants were basically citizens of the polis. On the other hand, the foreign trade and the state planning had the objective of guaranteeing foodstuff for the city; it was carried essentially by foreign traders and was regulated by the state.

Polanyi went deep into the differences between these two kinds of trade, explaining the characteristics of each one. The basic difference for him was based on the persons who carried through the commerce. The internal trader who worked in the agora was called kapelos, who was an Athenian citizen and traded to make a living. It was his choice to work in the agora, but he also had the possibility to work in other economic activities, because as a citizen of the polis he had all the corresponding rights. On the other hand, the external trader, called emporos, was a foreigner; therefore he did not have any rights in the polis, and lived off the commerce for surviving. He was not part of any polis, and the only activity left for him was being an emporos. It was not a choice, but a consequence of his condition of foreigner (Polanyi, 1977, ch. 13).

The presence of the emporos, the external trader, was normally a consequence of wars between cities. They were people whose polis had been destroyed or dominated by other cities during a war, and so became people without a homeland, consequently without any rights. Due to this, the only possible economic activity left for them to survive was to become an emporos. Some of them lived completely outside the cities, traveling from one polis to another. Others were more fixed, living as foreigners in a specific polis and traveling to work (Polanyi, 1977, ch. 13). 
For Polanyi, this difference shows how separate were the two systems: they did not have anything in common. The internal market, or the agora, was essentially part of the city; it was made by citizens and with the purpose to serve their fellows. On the other side, the foreign trade was essentially an external issue; it was made by foreigners, regulated by the state, and its main purpose was to guarantee the subsistence of the city, under the control of the State (Polanyi, 1977, ch. 13). The connection between both systems was made exclusively by the state, which controlled the quantities and prices of any transaction of the foreign trade; with this mechanism it could regulate the imports of food and consequently the level of supply of the internal market. The decision about the quantity allowed to enter in the city was made according to the necessities of the polis in each specific period. The state also bought foodstuff itself, to hold supplies for periods of crisis. Once again, this mechanism of regulating completely the foreign trade and the connection of it with the internal market was based on the purpose of caring about the livelihood of its citizens, protecting the city and its people from any kind of trouble (Polanyi, 1977, ch. 13).

Polanyi says that the two markets were so completely separate that their prices sometimes were extremely different, mostly on times of crises of supply. The internal price was not much volatile, because the state always controlled it, but the external price was really volatile, due to these problems (Polanyi, 1977, ch. 13). The relative stability of the internal price can be explained because the city controlled the imports of grain in the way to stabilize the prices in the agora at the level aimed, while the external price was really volatile, as it depended on the international supply of foodstuff. And due to the possibility that the suppliers could have problems of production as, for example, bad weather or political issues with neighbors, the external price could fluctuate getting far from the "normal" one.

The characteristics of the money in Athens are another important point made by Polanyi to show how separate the two systems were. According to him, the contemporary concept of money did not exist in the classical Athenian economy. $\mathrm{He}$ argues that money and commerce were two independent institutions, not related as they are in our days.

Money for the Greeks was an institution of the city, and not basically a means of exchange. Money in Greece did not vary its value according to its amount in the economy, and the metal also did not possess any intrinsic value. Its value was given by the city, which determined which would be its price and how much currency would be allowed to circulate in the economy (Polanyi, 1977, ch. 16).

Moreover, they had different kinds of money for diverse uses; the system was not unified. They had an internal money that served for the exchange of goods in the agora and, as explained previously, it did not vary its value and did not suffer from inflation, its price was defined by the city and for the city interests. This means that it also served as another control of the economy by the city, in the same way of all other factors already explained. The city could change the value of the money when it found necessary in order to maintain the stability. On the other hand, 
there was also an external type of money, used only in the foreign market for the payment of the emporos (Polanyi, 1977, p. 258).

The fundamental distinction in Greek money uses was the distinction between local and external money; the dichotomy was of the sharpest. Silver coins of small denomination and, particularly after the fourth century, bronze coins, were used for local trade or the agora, while silver coins of larger denomination, such as the stater, were used in external trade.

There was no exchange between those currencies; they were completely separate, used in different ways in two distinct markets. So, Polanyi's conclusion about this topic is that money and commerce were different and independent things. Money was used as another mechanism to separate the two markets and to allow the city to protect its citizens and reach its objectives in the economy. In no way the money had the same characteristics that it possesses today.

Polanyi's words (1977, p. 198) are perfect to sum up these ideas about the existence of two separate economic spheres:

To sum up: different types of traders, then, were engaged in local and in foreign trade. The two forms of trade were sharply distinct. Local trade - and no other trade - was market trade. Overseas trade was partly administered trade, partly gift trade, and the stray market elements that made appearances here were relatively unimportant.

\section{Imperialism and Politics}

Two important aspects of Polanyi's description of ancient Athens are the role of the imperialism and of politics for its economic system.

Imperialism in Athens meant the use of its naval military force to control the routes of commerce and to look up for new ones. Athens had the greatest naval force of that time, and with it Athens could secure the grain imports and the supplies for the society.

The interesting aspect of this situation is that, for Polanyi, Athenian imperialism was complementary to its democracy and internal market policies. For him, the war against the Persians made the city realize that it needed to have some external control and to guarantee the supply of food, since it lacks enough arable lands (Polanyi, 1977, ch. 12).

The war showed that these supplies could be easily cut of by enemies looking forward to dominate Greece. Thus, the development of an enormous naval fleet and the control of the maritime commerce of the Mediterranean had this economic objective.

External politics worked the same way. Diplomacy was used to guarantee the imports of grains through allies and other states. The city had a great structure of 
messengers and emissaries whose function was to negotiate the imports with other places (Polanyi, 1977, ch. 14). So, Athens used imperialism and politics as a complement to its economic system, with the objective of guaranteeing the imports of grain and the livelihood of their citizens.

It is important to remind that these mechanisms were not exclusively used by Athens. Almost every polis of the Classical period adopted these attitudes, trying to guarantee the food and the survival of their citizens. The fundamental difference is that Athens was by far the most successful in this task, being the one that controlled the major routes and who had the biggest quantity of allies; the relation with some of these allies had been settled through diplomatic means, but other allies had been signed through the use of military force.

\section{Why the duality?}

With Polanyi's description of the economy of ancient Athens, it results easy to answer the question raised at the beginning of the section: why did Athens create a system combining market with state planning instead of choosing only one of these options?

The answer is a summary of his interpretation: this mixed system was seen as necessary to maintain the livelihood of the citizens. Polanyi tried to show during all his analyses that Athens had innumerable geographic and political difficulties to guarantee its imports of grains. As we discussed, after Athens became a big city, it could not survive only with its own production: ${ }^{6}$ the imports of foodstuff were essential, because its own lands could not provide the entire necessary amount, and so this problem forced Athens to import. And due to the political problems of importing foodstuff from other lands, as its enemies tried to destroy Athens, the city was also forced to develop a system to control its foreign trade (Polanyi, 1977, ch. 14).

Athens did not choose the system; it was almost forced to adopt the external monopoly, despite the efficiency of its market. It was the only way that the city found to assure its survival, because in any other case it could have suffered with a series of external shocks and problems of supply during its history.

And why the internal market? As we have already explained, it was the best way developed by the city to allocate efficiently its resources and, besides, it was used as a redistributive device. ${ }^{7}$ In normal periods the city let the market work free, as it was an efficient way to allocate its resources; however, in moments of crises, Athens could use the market to redistribute, controlling prices making sure that all

\footnotetext{
${ }^{6}$ Polanyi (1977, p. 201) mentions that, according to calculations from A.W. Gomme, the population of the Attica was ranged between 200.000 and 300.000 people in the glorious fourth century B.C., but domestic crops could support a population of only 75.000.

${ }^{7}$ The city did not have an active role in the emergence of the local market (the agora); however, according to Polanyi (2001, ch. 5), all the cities controlled the expansion of these markets. So, if the state did not need to make efforts to develop a market, it was really concerned in creating barriers to its expansion.
} 
its citizens could have access to some means of survival. There existed, therefore, important reasons for the existence of the duality in Athens: it was rather a pioneer on the internal side, as it was one the first economies in history to develop an important market, but it adapted its workings to the external conditions on the other side. In Polanyi's words (1977, p. 199):

The answer, we submit, lays in the geographical and political configuration of the regions in which grain supplies and routes of communication were situated. These conditions, under which military and diplomatic means had to be employed to ensure that supplies were forthcoming, as well as the safety of the trade routes themselves, determined the methods and organization of grain trade.

\section{The end of the Classical system}

Concluding his analysis, Polanyi describes the end of the classical system and its transformation into an external market system. According to him, by the end of the fourth century, short before the Macedonian invasion, diverse characteristics of an external market could be found in Athens. It was still not a complete market system, but some characteristics of it could be already perceived. The main reason for this development was the decay of the polis. Its weakness was mainly due to many wars, especially the Peloponnesian one; these wars undermined the control Athens had over trade and routes, reducing its military force, and so the city lost the conditions to exert an external monopoly (Polanyi, 1977, ch. 15).

Two main characteristics that could be observed in the beginning of this phase differed from the previous status quo: the freedom for the emporos and the development of the emporium, the external market. The first one was the fact that the merchants started to decide where to sell their products, looking for the highest price offered. The traders started to look for the places paying the best price, and were not hostages of the city anymore.

The second characteristic observed was the initial development of the emporium, markets for external products located in the port of the city, sold by the emporos, the foreign traders. These markets started to develop all over the Mediterranean and were the places were the traders could look for the best selling price.

This process developed really fast and started to replace the control exerted by the polis. Later, with the military success of Alexander, he had conditions to unify the routes, the currencies, the taxes, and thus the development of the market was completed. His empire controlled all the Greek Mediterranean and could guarantee the total freedom of external commerce. The cities did not have more military force nor could exert any type of mechanism to intervene in the market ${ }^{8}$ (Polanyi, 1977, ch. 15).

\footnotetext{
${ }^{8}$ This process of the development of a unified Mediterranean market is analogous to the one observed
} 
This was the end of the dual system; it was also the end of the classical Greek period and the beginning of the Hellenistic period. It can be said that for Polanyi the decay of the city-state and the sprouting of the external market are processes intimately connected; it was the loss of the force of the cities that led to the end of the system. It was also the end of the protection of the citizens by the city, a period in which Athens sought to guarantee the livelihood, i.e., a minimum level of subsistence, for its people.

\section{CONCLUSIONS: POLANYI, THE GREEKS AND SOME LESSONS FOR THE PRESENT}

For Polanyi, Athens had a complex economic system in which the two main actors of our economic scene, the market and the state, already played important roles. It is also one the few economic forms seen in history that was really concerned with the well-being of its people, and developed for that purpose some economic devices to guarantee the livelihood of the citizens. The system joined economic rationality and efficiency with social consciousness and redistributive aim. As Polanyi (1977, p. 274) said:

We might, in contrast, sum up the Greek contribution to human economy by saying that the Greeks almost singlehandedly developed both types of economy - the market and exchange type as well as the planning and redistributive type - to their highest form reached up till then.

This account of the Greek economy and society can be seen in the light of one of the main concepts developed by Polanyi, the idea of Double Movement, already discussed. Polanyi went back to Greek history to show that these concerns with the possibly disruptive role of the markets were also present in those times but, differently from the non-interventionist view so fashionable in our modern market economies, the Greeks developed some devices to protect their society from the abuse of the markets.

The whole development of the Greek polis was based on the fundamental idea that the city should protect its own citizens, shielding them from the lack of minimum conditions for survival. To achieve this end, they understood that the market should be controlled, imposing boundaries as to safeguard the society from its disruptive side.

It is clear for us that all the insights of Polanyi about the Greek economy tried to show that for them the market was an important part of, but not the whole, economy. His work emphasizes that the Athenians were step ahead of Polanyi's

by Polanyi of the development of the national states in Europe. To read more about this, see Polanyi (2001, especially, ch. 5). 
own time because they had the notion that some important aspects of their livelihood were too crucial to let them rely only on the markets.

Polanyi's analysis of the consequences of the industrial revolution, as well as his views on the importance of the Ancient societies for our comprehension of the role of the market in the economy, are part of the debates of the mid-twentieth century about the importance of the state as a regulator of the economy. One political consequence of these discussions was the development of the Welfare State in many parts of the world, especially in the more democratic societies, giving back to the state the duty to regulate and to look for the best possible organization of the economy. ${ }^{9}$ In this way, it is important to praise Polanyi's work, as his ideas launched many discussions about the place of the economy in society. As Block (2001, p. xxxvi) says "Polanyi's vision depends on expanding the role of government both domestically and internationally [...] For him, a substantial governmental role is indispensable for managing the fictitious commodities."

There is one last conclusion to which we arrive at, based on Polanyi's work, that is also an expression of desire for the present times. As we emphasized, Polanyi's main concern was to show that the market per se is not a sufficient mechanism to organize the economy as to guarantee the livelihood of the human beings, and that other devices should be developed by the states (and societies) to prevent the market from achieving a complete freedom. ${ }^{10}$ We believe that in these days of globalization and neo-liberalism, these concerns raised by Polanyi, and their significance in our times, should be permanently brought back to the discussion so that the problems of human livelihood in our days could be better dealt with.

\section{REFERENCES}

ADAMAN, Fikret \& Pat DEVINE, eds. (2002). Economy and Society: money, capitalism and transition. Montreal: Black Rose.

AUSTIN, M,M \& VIDAL-NAQUET, P. (1977). Economic and Social History of Ancient Greece: An Introduction. Berkeley: University of California Press. 1st. ed.

BAUM, Gregory (1996). Karl Polanyi on Ethics and Economics. Quebec: McGill-Queen's University Press.

BLOCK, Fred (2001). "Introduction" to The Great Transformation. In Polanyi, Karl [1944]. The Great Transformation. Boston: Beacon Press. 2nd ed.

BLOCK, Fred (2003). "Karl Polanyi and the Writing of 'The Great Transformation"”. Theory and Society, 32 (3): 275-306.

\footnotetext{
${ }^{9}$ Fred Block suggests that when Polanyi was writing the Great Transformation, he thought that "market societies could be fundamentally reshaped by deeply democratic reforms". However, after writing his essay "Our Obsolete Market Mentality" (in Polanyi, 1968) he realized that he could not influence the flow of events so he shifted "..his intellectual energies toward the analysis of primitive and archaic economies” (Block, 2003, p.298).

${ }^{10}$ For a contemporary criticism of the role of the markets and a defense of the public intervention at them see Stiglitz (2002) and Bresser-Pereira (2007).
} 
BRESSER-PEREIRA, Luiz Carlos (2007). Macroeconomia da estagnação: crítica da ortodoxia convencional no Brasil pós-1994. São Paulo: Ed. 34.

FINLEY, Moses I. (1991) [1963].The Ancient Greeks. New York: Penguin.

JOHNSON, Allen W. \& TIMOTHY Earle (2000). The evolution of human societies: from foraging group to agrarian state. Stanford (CA): Stanford University Press, $2^{\mathrm{a}}$ ed.

LATHAM, A. J. H. (1998). "Karl Polanyi: some observations". Paper presented at the "Global History Seminar" of the Institute of Historical Research of the University College of Swansea. (Available at http://www.history.ac.uk/eseminars/sem3.html, accessed in 28/07/06)

POLANYI, Karl (1968). Primitive, Archaic and Modern Economies. (Posthumously edited book, George Dalton, org.). New York: Doubleday.

POLANYI, Karl (1977). The Livelihood of Man. (Posthumously edited book, Harry Pearson, org.). New York: Academic Press.

POLANYI, Karl (2001) [1944]. The Great Transformation. Boston: Beacon Press. 2nd ed.

POLANYI, Karl; Arensberg, Conrad M. \& Pearson, Harry W. (eds) (1957). Trade and Markets in the Early Empires. Chicago: Free Press.

STANFIELD, James Ronald (1986). The Economic Thought of Karl Polanyi: live and livelihood. London: Macmillan.

STANFIELD, James Ronald (1994). "Karl Polanyi”. In Geoffrey Hodgson, Warren Samuels \& Marc Tool, eds, The Elgar Companion to Institutional and Evolutionary Economics. Aldershot: Edward Elgar, vol. 2, p. 166-169.

STIGLITZ, Joseph (2002). Globalization and its discontents. New York \& London: W.W.Norton.

TANDY, David W., org. (2001). Prehistory and history: ethnicity, class and political economy. Montreal: Black Rose. 